\title{
Hydrogeochemical Evolution and Control Mechanism of Underground Multiaquifer System in Coal Mine Area
}

\author{
Qiding Ju $\mathbb{D}^{1,2}$ Yu Liu ${ }^{1},{ }^{1}$ Youbiao Hu, ${ }^{2}$ Yuquan Wang, ${ }^{3}$ Qimeng Liu, ${ }^{2}$ and Zitao Wang ${ }^{2}$ \\ ${ }^{1}$ State Key Laboratory of Mining Response and Disaster Prevention and Control in Deep Coal Mines, Anhui University of Science \\ and Technology, Huainan 232001, China \\ ${ }^{2}$ School of Earth and Environment, Anhui University of Science and Technology, Huainan 232001, China \\ ${ }^{3}$ Wanbei Coal-electricity Group Company, Suzhou 234001, China
}

Correspondence should be addressed to Yu Liu; yliu@aust.edu.cn

Received 26 August 2020; Revised 29 September 2020; Accepted 16 October 2020; Published 2 November 2020

Academic Editor: Bo Li

Copyright (C) 2020 Qiding Ju et al. This is an open access article distributed under the Creative Commons Attribution License, which permits unrestricted use, distribution, and reproduction in any medium, provided the original work is properly cited.

\begin{abstract}
Mining activities interfere into the natural groundwater chemical environment, which may lead to hydrogeochemical changes of aquifers and mine water inrush disasters. The study of hydrogeochemical evolution processes of underground aquifers is helpful to the prevention and control of mine water inrush. The results show that the study area is mainly impacted by four hydrogeochemical processes: dissolution, cation exchange, desulfurization and reduction, and pyrite oxidation. The Cenozoic aquifers are dominated by carbonate dissolution and desulfurization. The Permian aquifers are impacted mainly by cation exchange and sulfate dissolution, followed by pyrite oxidation. The Carboniferous aquifers are mainly impacted by dissolving sulfate, followed by pyrite oxidation and cation exchange. The hydrogeochemical evolution of the aquifers was controlled by mining activities and tectonic changes, and a certain regularity in space. For the Cenozoic aquifers, sulfate dissolution and cation exchange increase from west to east, and desulfurization weakens. For the Permian aquifers, cation exchange and sulfate dissolution are stronger near synclines and faults, pyrite oxidation is enhanced, and desulfurization decreases from the middle to the east of the mining area. For the Carboniferous aquifers, there is a higher dissolution of rock salt, pyrite oxidation, and cation exchange from west to east, and the desulfurization effect weakens.
\end{abstract}

\section{Introduction}

Human activities have led to different deterioration trends in the global groundwater environment; this trend is developing in a negative direction [1-3]. The mine water inrush and water contamination are two common groundwater problems in mining areas of China. After mining, the chemical environment of the groundwater becomes complex, forming a multiaquifer system with different hydrogeochemical characteristics. This leads to a complex groundwater flow field and chemical field. As the aquifer connects with the structure, different aquifers connect to form a water filling channel, which causes water inrush accidents and water pollution $[4,5]$. This highlights the importance of studying water quality types and the hydrogeochemical evolution characteristics of underground aquifers, which can provide the basis for the safe production of coal mines and the full utilization of water resources.

Variations in conventional ion levels in groundwater represent hydrogeochemical evolution processes. Hydrogeochemical analysis methods used to determine the evolution of groundwater chemical composition include: hydrogeochemical maps, multivariate statistical analysis, and GIS spatial analysis $[6-8]$. Huang et al. $[9,10]$ used a Piper diagram, Gibbs diagram, and Ion proportion coefficient diagram to analyse the chemical characteristics of groundwater. Multivariate statistical analyses were used to study the hydrogeochemical evolution process mainly include factor analysis, principal component analysis, and cluster analysis. Comprehensive consideration time and space indicators, Chen et al. [11] successfully revealed the chemical characteristics and spatiotemporal evolution mechanism of groundwater by 
principal component analysis. Zhang et al. [12] studied the relationship between the hydrogeochemical characteristics of groundwater and the multilayer aquifer in a Karst subsided column mine, by combining a chemical analysis with a principal component analysis. Gomo et al. [13] used the traditional hydrochemical analysis method to describe the underground hydrogeochemical process of a submerged mine and analysed the groundwater chemical types and water quality evolution. Sunkari et al. [14] used factor analysis to transform original ion concentration data into a normal distribution, effectively explained the sourcing of groundwater ions. In recent years, based on GIS spatial interpolation analysis, some researchers studied the hydrochemical evolution process of underground aquifer, drew the hydrogeochemical action spatial map, and quantitatively described the hydrochemical spatial evolution process and control factors $[15,16]$. In summary, hydrochemical analysis, factor analysis, and GIS spatial analysis can be combined to describe the hydrogeochemical evolution process and its controlling factors; this provides important information about the hydrogeological background.

The Hengyuan coal mine, operated by the Wanbei Coal Electricity Group, has complicated hydrogeological conditions. The mine is threatened by high-pressure limestone water and sandstone water from the coal seam roof and floor and poses potential safety hazards, such as the collapse of the karst column and water disasters in the loose layers. In this paper, factor analysis is used to name the main hydrogeochemical processes clearly and accurately, and then, it is combined with traditional hydrochemical methods. Finally, GIS spatial analysis reveals the hydrochemical evolution process of multiaquifer system. The study focused on identifying the hydrogeological and geochemical characteristics and control factors of water-filled aquifers. It provides a scientific basis for accurately identifying potential water inrush hazard sources and a basis for the rational protection and utilization of water resources. In addition, this method has a certain guiding significance for the concealed coalfields in North China.

\section{Materials and Methods}

2.1. Study Area and Hydrogeological Setting. The Hengyuan coal mine is located in Huaibei City in north of Anhui Province, China (Figure 1(a)). The geographical coordinates are $116^{\circ} 36^{\prime} 04^{\prime \prime}-116^{\circ} 43^{\prime} 22^{\prime \prime} \mathrm{E}$ and $33^{\circ} 54^{\prime} 30^{\prime \prime}-34^{\circ} 0^{\prime} 59^{\prime \prime} \mathrm{N}$. The terrain in the mining area is flat, and the natural surface elevation is approximately 30 to $36 \mathrm{~m}$, with a tendency to incline from the northwest to southeast. There is no bedrock outcrop; instead, the area is covered by an extremely thick Cenozoic loose layer. The climate in this area is mild, exhibiting a north temperate monsoon area marine continental climate. The annual average temperature is $16.8^{\circ} \mathrm{C}$, the maximum temperature is $37^{\circ} \mathrm{C}$ (July 2019), and the minimum temperature is $-7^{\circ} \mathrm{C}$ (January 2019). The average annual rainfall is $1067 \mathrm{~mm}$, and the rainfall is mainly concentrated in July and August.

The strata in this area are rarely exposed and are mostly covered by Quaternary alluvial and proluvial plain materials
(Figure 1(b)). Drilling records show that the strata, from old to new, are Ordovician $\left(\mathrm{O}_{1+2}\right)$, Carboniferous $\left(\mathrm{C}_{2+3}\right)$, Permian $(\mathrm{P})$, Tertiary $(\mathrm{N})$, and Quaternary $(\mathrm{Q})$. The coal-bearing strata in the Hengyuan coal mine include the lower Permian Shanxi Formation and Lower Shihezi Formation. There is no minable coal seam in upper Shihezi Formation, so it was not studied. The coal-bearing strata are $343.20 \mathrm{~m}$ thick and include eight coal seams (formations) and 2-17 coal seams. The total thickness of the coal seam is $5.52 \mathrm{~m}$. The average total thickness of the mineable or partially mineable coal seam is $4.82 \mathrm{~m}$, accounting for $87.3 \%$ of the total thickness of the coal seam. For all the seams, 4 and 6 coal seams are the main mineable coal seams, with an average total thickness of $4.48 \mathrm{~m}$, accounting for $81.2 \%$ of the total thickness of the mineable coal seams.

The Cenozoic unconsolidated aquifer can be divided into three aquifers groups from top to bottom. The Cenozoic bottom aquifer forms a "skylight," due to the lack of aquiclude in local areas, which directly cover the coal-bearing strata. They may also become the water supply source into the Permian aquifer. The main source of recharge is the regional interlayer runoff; the lithology of the Permian aquifer is composed of sandstone, mudstone, siltstone, and coal seam, with mostly mudstone and siltstone. The Permian aquifer is approximately $240 \mathrm{~m}$ thick, with a buried depth of approximately $500 \mathrm{~m}$. From the top to the bottom of the mine, the location and degree of fractures development in the main mining coal seams are divided across the fifth aquifer, the sixth aquifer, the seventh aquifer, and the eighth aquifer.

According to water level observations, the water level in 12 Carboniferous aquifer observation holes had dropped to $-146.14 \mathrm{~m}$ by the end of 2006 . The Carboniferous aquifer is the water supply source for coal seam mining and is one of the hidden dangers, as water may fill the 6 coal seams. The lithology of the Ordovician limestone karst fissure aquifer is light grey thick layered limestone, with different regular grey and light grey white stripes, and local dolomite. It is pure and brittle with a microcrystalline structure and high angle fractures. Under normal conditions, no direct water fills the mine pit. However, it is possible that a water inrush could occur, with Ordovician limestone water directly entering the mine pit. This could occur when the shaft and roadway engineering encounter a water-conducting fault or water flowing subsided column.

2.2. Methods. A total of 74 water samples were collected between January and July 2018 in the Hengyuan Coal Mine area. The samples included 9 samples from the Cenozoic aquifers, 35 samples from the Permian aquifers, and 30 samples from the carboniferous aquifers (Figure 1).

Before sampling, each clean $550 \mathrm{~mL}$ polypropylene bottle and cap was rinsed with water 3-5 times [17-19]. Each water sample was collected in a bottle, leaving a $5-10 \mathrm{ml}$ space at the top of the bottle. The temperature and $\mathrm{pH}$ were maintained at stable levels after the water samples were collected; a previously calibrated Hanna portable $\mathrm{pH}$ meter was used to measure all the parameters within five minutes. The water samples were put through a $0.45 \mu \mathrm{m}$ field filtering membrane, with each water sample divided into three bottles, 

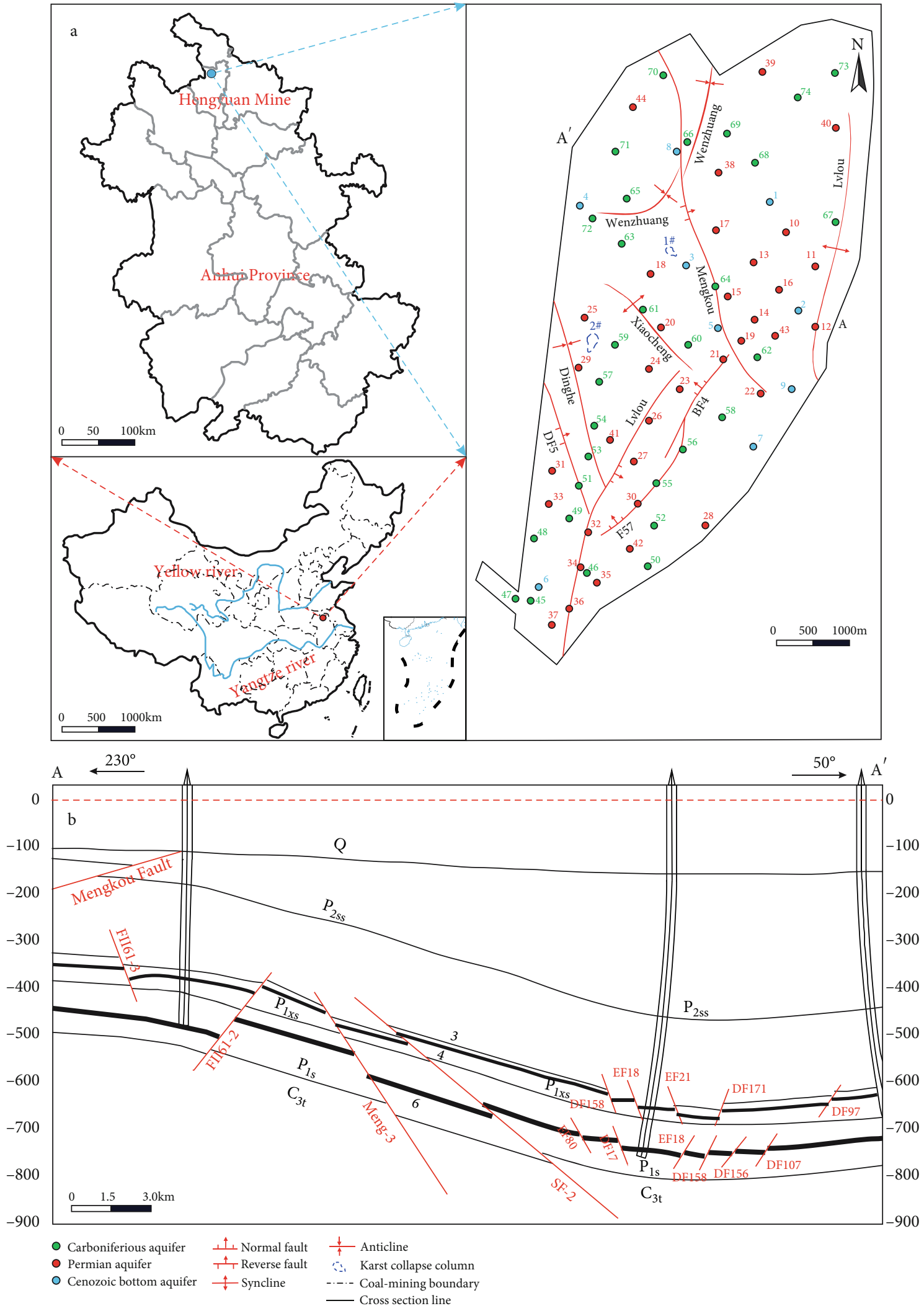

Figure 1: The map of the Hengyuan coal mine area, with the distribution of faults, folds, sampling sites, and cross section of the coal mine along line $\mathrm{A}-\mathrm{A}^{\prime}$. 
TABLE 1: Sample indexes-descriptive statistics.

\begin{tabular}{lcccccccccccc}
\hline \multirow{2}{*}{ Parameters } & \multicolumn{3}{c}{ The Cenozoic aquifer } & \multicolumn{3}{c}{ The Permian aquifer } & \multicolumn{3}{c}{ The carboniferous aquifer } \\
& Min & Max & Mean & Skewness & Min & Max & Mean & Skewness & Min & Max & Mean & Skewness \\
\hline $\mathrm{K}^{+}+\mathrm{Na}^{+}(\mathrm{mg} / \mathrm{L})$ & 111 & 202.47 & 152.71 & 0.26 & 578.6 & 1550.27 & 1036.94 & 0.05 & 168.65 & 813.98 & 398.6 & 0.48 \\
$\mathrm{Ca}^{2+}(\mathrm{mg} / \mathrm{L})$ & 79.55 & 124.73 & 99.89 & 0.24 & 1.13 & 63.15 & 25.59 & 0.63 & 2.42 & 447.56 & 202.17 & 0.09 \\
$\mathrm{Mg}^{2+}(\mathrm{mg} / \mathrm{L})$ & 28.81 & 81.12 & 54.93 & 0.09 & 1.17 & 38.66 & 13.73 & 0.8 & 5.53 & 323.69 & 121.44 & 1.09 \\
$\mathrm{Cl}^{-}(\mathrm{mg} / \mathrm{L})$ & 91.98 & 144.67 & 115.43 & 0.15 & 56.46 & 354.16 & 171.91 & 0.82 & 82.98 & 188.91 & 143.39 & -0.37 \\
$\mathrm{SO}_{4}^{2-}(\mathrm{mg} / \mathrm{L})$ & 207.06 & 417.26 & 283.62 & 1.01 & 833.2 & 2524.69 & 1668.09 & 0.45 & 1001.36 & 1770.6 & 1404.92 & -0.16 \\
$\mathrm{HCO}_{3}^{-}(\mathrm{mg} / \mathrm{L})$ & 279.83 & 541.86 & 419.79 & -0.35 & 164.21 & 692.17 & 435.72 & -0.14 & 129.91 & 340.89 & 240.28 & 0.29 \\
$\mathrm{TDS}(\mathrm{mg} / \mathrm{L})$ & 899.23 & 1239.45 & 1058.24 & 0.22 & 2023.48 & 5005.01 & 3371.35 & 0.32 & 2020.85 & 3088.47 & 2534.47 & 0.02 \\
$\mathrm{PH}$ & 7.3 & 8.4 & 7.57 & 2.39 & 7.79 & 8.32 & 7.94 & 1.96 & 7.1 & 8.3 & 7.68 & -0.6 \\
\hline
\end{tabular}

two for anion analysis, and the other for standby experiment. The water samples were maintained at a low temperature to support the cation analysis. This prevented a chemical reaction [20, 21]. Eight general hydrogeochemical parameters were tested: $\mathrm{K}^{+}+\mathrm{Na}^{+}, \mathrm{Ca}^{2+}, \mathrm{Mg}^{2+}, \mathrm{Cl}^{-}, \mathrm{SO}_{4}{ }^{2-}, \mathrm{HCO}_{3}{ }^{-}, \mathrm{pH}$, and TDS. The samples for cation analysis were acidified with nitric acid to $\mathrm{pH} \leq 2$. The tests were conducted within 24 hours after sampling at the Anhui University of Science and Technology, Quality Inspection Center. The $\mathrm{Cl}^{-}, \mathrm{SO}_{4}{ }^{2}$ -, and $\mathrm{HCO}_{3}{ }^{-}$tests were conducted using ion chromatography; and the $\mathrm{K}^{+}+\mathrm{Na}^{+}, \mathrm{Ca}^{2+}$, and $\mathrm{Mg}^{2+}$ tests were conducted using inductively coupled plasma mass spectrometry. To review the reliability of test results, the anion and cation balance was calculated to confirm that any error was the standard limit of $\pm 5 \%$ [22].

In this paper, the SPSS26.0 software was used to generate a descriptive statistical analysis of the data (Table 1). Then, the SPSS software was used to conduct a factor analysis on the hydrochemical data. The factor extraction method adopted a principal component analysis to reduce interference from redundant data, the main factor score equation is obtained by factor analysis, and the scores of different sampling points are obtained by substituting the variable values to equation. Finally, the contour map of the main factor score was drawn by using Surfer software. Thus, the hydrogeochemical characteristics and evolution process of each underground aquifer by spatial analysis of factor score.

\section{Results and Discussion}

3.1. Statistics Analysis. Table 1 shows the results of the hydrochemical statistical analysis for the samples from the Cenozoic aquifers, Permian aquifers, and carboniferous aquifers. The analysis shows that the $\mathrm{pH}$ value of all samples varies from 7.10 to 8.32 , making the entire underground aquifer weakly alkaline. In the weakly alkaline environment, the $\mathrm{CO}_{3}{ }^{2-}$ levels are less than $5 \%$ of the sum of $\mathrm{HCO}_{3}{ }^{-}$and $\mathrm{CO}_{3}{ }^{2-}$, making it unimportant to assess $\mathrm{CO}_{3}{ }^{2-}$ levels.

The average salinity of the Cenozoic aquifers is $1058.24 \mathrm{mg} / \mathrm{L}$. The cation concentrations in the water overall is highest for $\mathrm{K}^{+}+\mathrm{Na}^{+}$, followed in descending order by $\mathrm{Ca}^{2+}$ and $\mathrm{Mg}^{2+}$. The anion concentrations are the highest for $\mathrm{HCO}_{3}{ }^{-}$, followed in descending order by $\mathrm{SO}_{4}{ }^{2-}$, and $\mathrm{Cl}^{-}$. The mass concentration of $\mathrm{K}^{+}+\mathrm{Na}^{+}$is 1.5 times and 2.8 times of the mass concentration of $\mathrm{Ca}^{2+}$ and $\mathrm{Mg}^{2+}$, respectively. The mass concentration of $\mathrm{HCO}_{3}{ }^{-}$is 1.5 times and 3.6 times of $\mathrm{SO}_{4}^{2-}$ and $\mathrm{Cl}^{-}$, respectively.

The average salinity of Permian aquifers is $3371.35 \mathrm{mg} / \mathrm{L}$. The cation concentrations in the water overall are the same as Cenozoic aquifers, and the anion concentrations are the highest for $\mathrm{SO}_{4}{ }^{2-}$, followed in descending order by $\mathrm{HCO}_{3}{ }^{-}$, and $\mathrm{Cl}^{-}$. The mass concentration of $\mathrm{K}^{+}+\mathrm{Na}^{+}$is 40.5 times and 75.5 times of the mass concentration of $\mathrm{Ca}^{2+}$ and $\mathrm{Mg}^{2+}$, respectively. The mass concentration of $\mathrm{SO}_{4}{ }^{2-}$ is 3.8 times and 9.7 times of $\mathrm{HCO}_{3}{ }^{-}$and $\mathrm{Cl}^{-}$, respectively.

The average salinity of the carboniferous aquifers is $2534.47 \mathrm{mg} / \mathrm{L}$. The cation concentrations in the water overall are the same as Cenozoic and Permian aquifers, and the anion concentrations are the same as Permian aquifers. This is consistent with the change of ion concentration in the coal measure sandstone aquifer. The mass concentration of $\mathrm{K}^{+}+\mathrm{Na}^{+}$is 1.9 and 3.3 times of the mass concentrations of $\mathrm{Ca}^{2+}$ and $\mathrm{Mg}^{2+}$, respectively. The mass concentration of $\mathrm{SO}_{4}{ }^{2-}$ is 5.8 and 9.8 times of $\mathrm{HCO}_{3}{ }^{-}$and $\mathrm{Cl}^{-}$, respectively. The concentration skewness coefficient of each ionizer in the three aquifers is close to 0 and adheres to a normal stable distribution. This indicates that the distribution of ions in the aquifer is relatively stable and is less disturbed by hydrogeological conditions and other factors.

3.2. Analysis of Hydrochemical Components. The hydrochemical types and distribution of all aquifers in the study area are shown in Figure 2. The distribution of water sample drops in the Cenozoic aquifers is relatively concentrated, with alkaline metal ions $\mathrm{Ca}^{2+}$ and $\mathrm{Mg}^{2+}$ present at greater concentrations than alkali metal ions $\mathrm{K}^{+}+\mathrm{Na}^{+}$. The percentage of $\mathrm{SO}_{4}{ }^{2-}$ exceeds $80 \%$, and the percentage of $\mathrm{HCO}_{3}{ }^{-}$ equivalent ranges from 40 to $60 \%$. Therefore, the hydrochemical type of the quaternary aquifer is mainly the $\mathrm{SO}_{4} \cdot \mathrm{HCO}_{3}-\mathrm{Na} \cdot \mathrm{Ca}(\mathrm{Mg})$ type. The distribution of water samples in the Permian aquifers is also relatively concentrated. The percentages of $\mathrm{Ca}^{2+}$ and $\mathrm{SO}_{4}{ }^{2-}$ equivalents both exceed $80 \%$, and the percentage of $\mathrm{Cl}^{-}$equivalent is within the range of $40-90 \%$. This indicates that the hydrochemical type is the $\mathrm{SO}_{4} \cdot \mathrm{Cl}-\mathrm{Ca}$ type. The water samples in the Carboniferous aquifers are relatively dispersed, with hydrochemical types of $\mathrm{SO}_{4} \cdot \mathrm{Cl}-\mathrm{Ca} \cdot \mathrm{Mg}$ or $\mathrm{SO}_{4} \cdot \mathrm{Cl}-\mathrm{Na} \cdot \mathrm{Ca}(\mathrm{Mg})$. This overlaps with the sample drops of the Cenozoic aquifer and the Permian aquifers, indicating that the Carboniferous aquifers have 


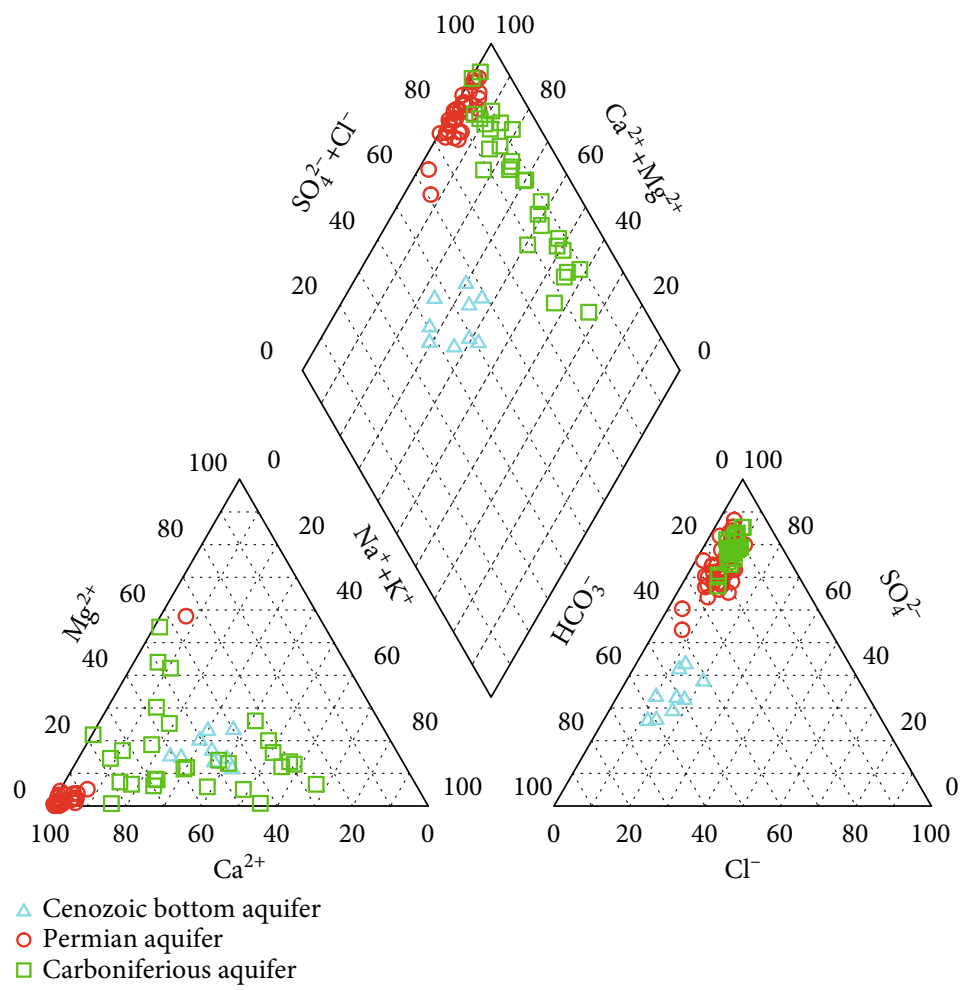

Figure 2: Piper diagram of groundwater samples from the Cenozoic, Permian, and Carboniferous aquifers.

similar hydrogeochemical characteristics and corresponding hydraulic relations.

The boxplot directly reflects the change of the ion levels in each aquifer [18]. Figures 3(a) and 3(d) show that the $\mathrm{K}^{+}+\mathrm{Na}^{+}$concentration in Permian aquifers is higher compared to the Carboniferous, due to the strong chloride dissolution effect in Permian aquifers. The levels in the Cenozoic aquifers are the lowest. $\mathrm{Cl}^{-}$in the aquifer is the most stable ion in groundwater, leaving the $\mathrm{Cl}^{-}$levels essentially unchanged. Figures 3(b) and 3(c) show that the $\mathrm{Ca}^{2+}$ and $\mathrm{Mg}^{2+}$ concentration in the Cenozoic and Carboniferous aquifers is significantly higher compared to the Permian aquifers. This is caused by the dissolution of carbonate and sulfate minerals. In Figures 3(e) and $3(\mathrm{f})$, the $\mathrm{SO}_{4}{ }^{2-}$ concentration in the Cenozoic to Permian and Carboniferous aquifers gradually increased overall. In contrast, the $\mathrm{HCO}_{3}{ }^{-}$concentration in the water from the Permian to Carboniferous aquifers gradually decreased. This was caused by the enhanced sulfate dissolution and weakened desulfurization acid. Therefore, high $\mathrm{HCO}_{3}{ }^{-}$ concentrations and low $\mathrm{Mg}^{2+}$ concentrations are characteristics of the three water-bearing strata. High $\mathrm{K}^{+}+\mathrm{Na}^{+}, \mathrm{SO}_{4}{ }^{2}$ ${ }^{-}$, and $\mathrm{HCO}_{3}{ }^{-}$concentrations and low $\mathrm{Ca}^{2+}$ and $\mathrm{Mg}^{2+}$ concentrations are the characteristics of the Permian aquifers. However, the Carboniferous aquifers are characterized by high $\mathrm{Ca}^{2+}, \mathrm{Mg}^{2+}$, and $\mathrm{SO}_{4}{ }^{2-}$ concentrations and low $\mathrm{HCO}_{3}{ }^{-}$concentrations. Because there are equivalent concentrations of the same ions in different aquifers, the simple comparison of changes in ion levels cannot reflect the main hydrogeochemical process and genesis.
3.3. Ion Source Analysis. There are differences in the ion combination ratio among groundwater components. As such, the source of groundwater chemical components can be determined using the ion proportion coefficient method [23]. The bubble diagram of the ion combination ratio of each aquifer is shown in Figure 4 . The bubble size indicates the change in the TDS concentrations of the samples.

$\mathrm{Cl}^{-}$is the most stable ion in groundwater, and the source of $\mathrm{Na}^{+}$can be characterized by analysing $\gamma\left(\mathrm{K}^{+}+\mathrm{Na}^{+}\right) / \gamma\left(\mathrm{Cl}^{-}\right)$ [24-27]. Figure 4(a) shows that $\gamma\left(\mathrm{K}^{+}+\mathrm{Na}^{+}\right) / \gamma\left(\mathrm{Cl}^{-}\right)>1$ in all water samples from the three aquifers, and the $\mathrm{Na}^{+}$concentration increases with as the TDS value increases. This shows that in addition to the $\mathrm{Na}^{+}$produced by the dissolution of salt rock, cation exchange is also a source of $\mathrm{Na}^{+}$. The value of $\gamma\left(\mathrm{K}^{+}+\mathrm{Na}^{+}\right) / \gamma\left(\mathrm{Cl}^{-}\right)$significantly exceeds 1 in the Permian aquifer, and the TDS value also exceeds the value in other aquifers. As such, cation exchange is stronger than in other aquifers, supporting the enrichment of $\mathrm{Na}^{+}$.

The source of $\mathrm{Ca}^{2+}$ and $\mathrm{Mg}^{2+}$ can be characterized by analysing $\gamma\left(\mathrm{Ca}^{2+}+\mathrm{Mg}^{2+}\right) /\left[\gamma\left(\mathrm{SO}_{4}{ }^{2-}\right)+0.5 \gamma\left(\mathrm{HCO}_{3}{ }^{-}\right)\right][28-$ 30]. Figure 4(b) shows that only a small number of the Cenozoic aquifer water samples fall above the $y=x$ line, and the rest of the samples fall below that line. In particular, the values of $\gamma\left(\mathrm{Ca}^{2+}+\mathrm{Mg}^{2+}\right) /\left[\gamma\left(\mathrm{SO}_{4}{ }^{2-}\right)+0.5 \gamma\left(\mathrm{HCO}_{3}{ }^{-}\right)\right]$in the Permian aquifer is far less than 1 . In addition, the TDS values in the Permian aquifer are significantly higher compared to other aquifers. It shows that cation exchange has occurred. Therefore, the dissolution of sulfate and carbonate is not the only source of $\mathrm{Ca}^{2+}$ and $\mathrm{Mg}^{2+}$, further confirming that alternate cation adsorption is reasonable. 


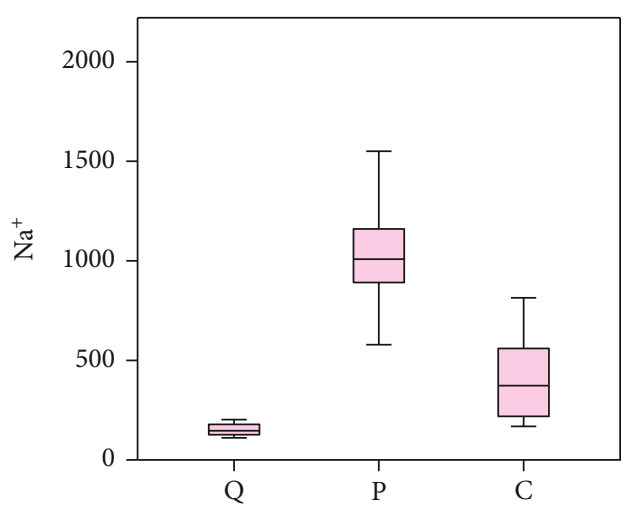

(a)

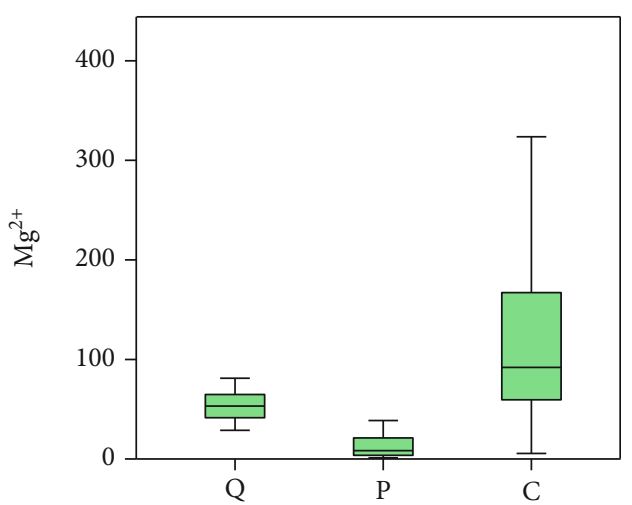

(c)

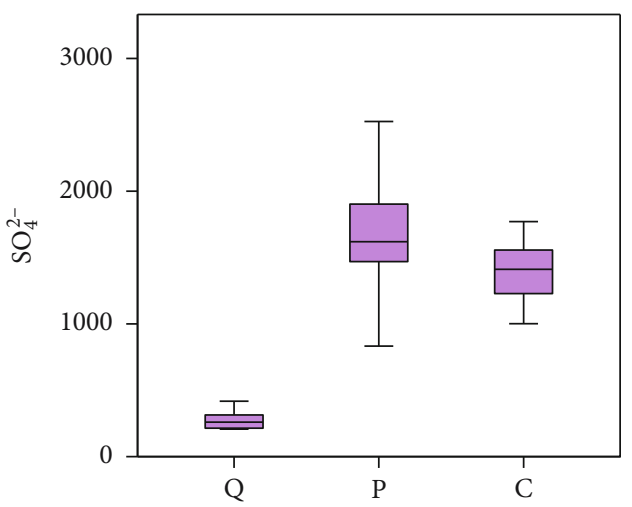

(e)

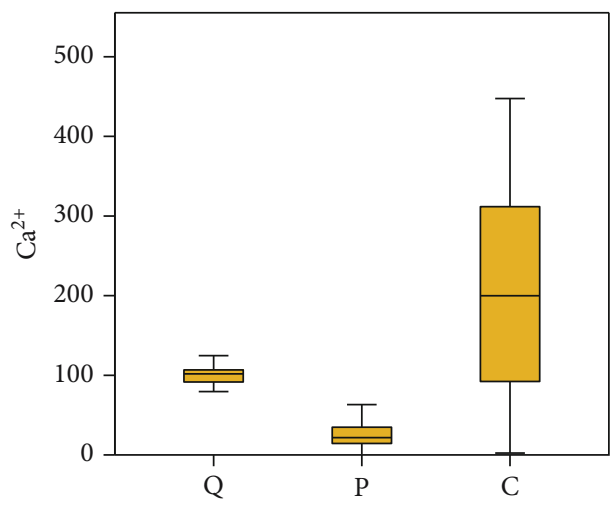

(b)

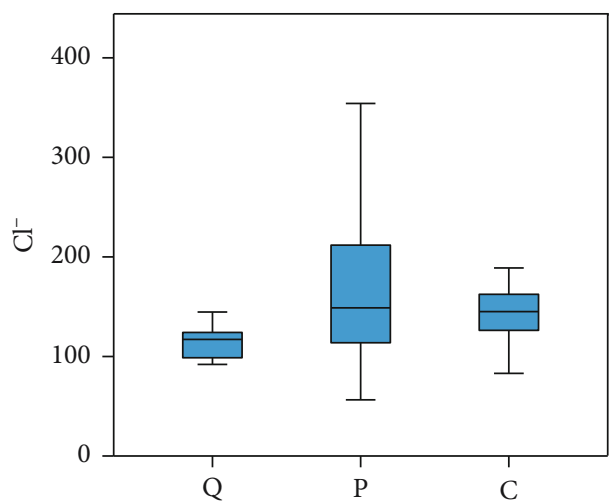

(d)

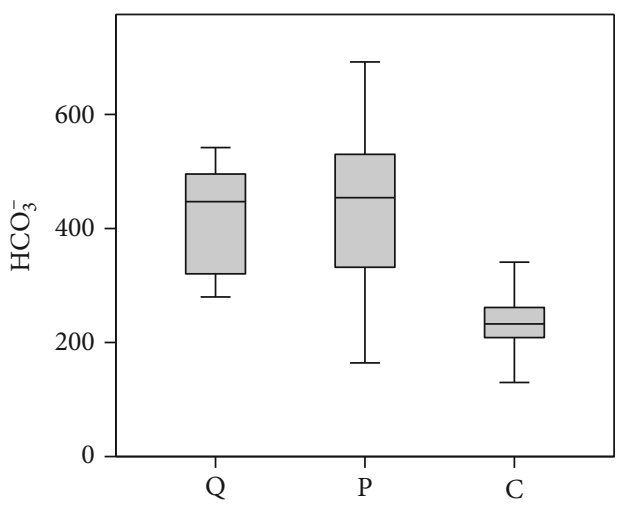

(f)

Figure 3: Ion box diagram.

When $\gamma\left(\mathrm{Ca}^{2+}+\mathrm{Mg}^{2+}\right) / 0.5 \gamma\left(\mathrm{HCO}_{3}{ }^{-}\right)=1$, it means that the $\mathrm{Ca}^{2+}, \mathrm{Mg}^{2+}$, and $\mathrm{HCO}_{3}{ }^{-}$in the groundwater are derived from carbonate dissolution [31]. The Cenozoic and Carboniferous aquifer samples fall above the $y=x$ line. The TDS values in the Carboniferous aquifer are significantly greater than in the Cenozoic aquifer. This indicates that $\mathrm{Ca}^{2+}$, $\mathrm{Mg}^{2+}$, and $\mathrm{HCO}_{3}{ }^{-}$are mainly derived from dissolution occurring in the Cenozoic and Carboniferous aquifer. A small number of the Permian aquifer samples are located above the line; however, the TDS values remain still higher compared to other aquifers. This indicates that the carbonate dissolution is not the only source of $\mathrm{Ca}^{2+}$ and $\mathrm{Mg}^{2+}$ and may also be caused by cation exchange in the Permian aquifer.
Most Permian aquifer samples align with the conditions of $\gamma\left(\mathrm{Ca}^{2+}+\mathrm{Mg}^{2+}\right) / 0.5 \gamma\left(\mathrm{HCO}_{3}{ }^{-}\right)<1$. This indicates that there are other sources of $\mathrm{HCO}_{3}{ }^{-}$, such as desulfurization.

Based on $\gamma\left(\mathrm{Ca}^{2+}+\mathrm{Mg}^{2+}\right) / \gamma\left(\mathrm{SO}_{4}{ }^{2-}\right)=1$, it appears that $\mathrm{Ca}^{2+}, \mathrm{Mg}^{2+}$, and $\mathrm{SO}_{4}{ }^{2-}$ are mainly derived from the sulfate dissolution in Figure 4(d) [32]. The $\mathrm{Ca}^{2+}$ and $\mathrm{Mg}^{2+}$ concentrations are low in the Permian aquifer; however, the TDS values are higher compared to other aquifers. This is due to the cation exchange, which facilitates the enrichment of $\mathrm{Na}^{+}$. In the Permian and Carboniferous aquifers, the ratio of $\gamma(\mathrm{C}$ $\left.\mathrm{a}^{2+}+\mathrm{Mg}^{2+}\right) / \gamma\left(\mathrm{SO}_{4}{ }^{2-}\right)$ in some samples is less than 1 , indicating that sulfate dissolution is not the only source of $\mathrm{Ca}^{2+}$, $\mathrm{Mg}^{2+}$, and $\mathrm{SO}_{4}{ }^{2-}$; pyrite oxidation may be another source. 


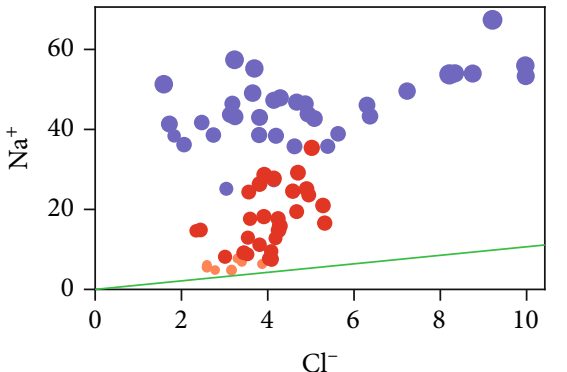

$-\mathrm{Q}$
$-\mathrm{P}$
$-\mathrm{C}$

(a)

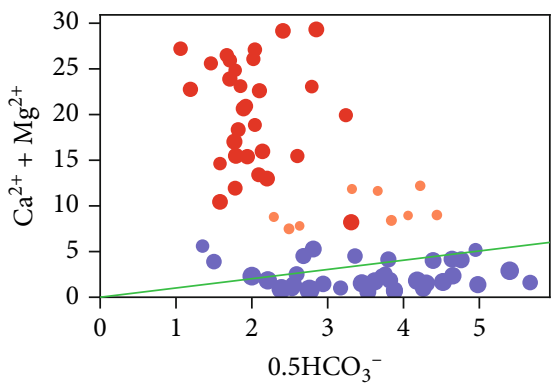

$-\mathrm{Q}$
$-\mathrm{P}$
$-\mathrm{C}$

(c)

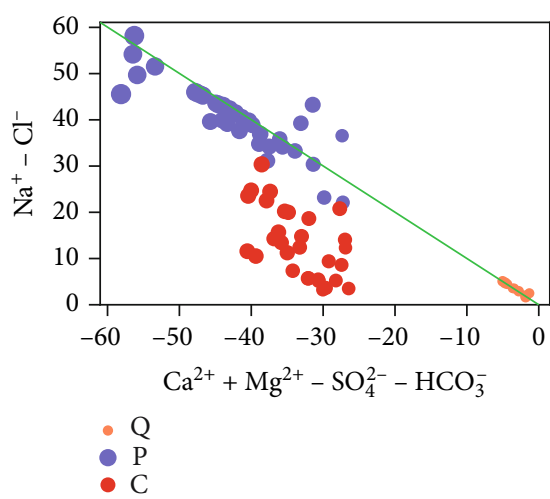

(e)

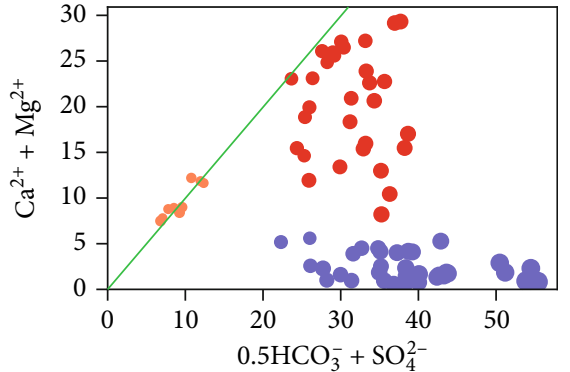

- Q

- $\mathrm{C}$

(b)

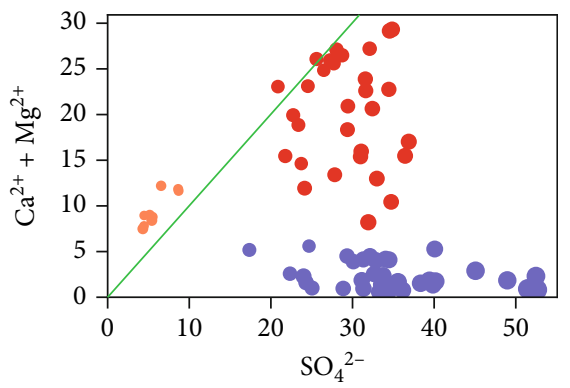

- Q

- $\mathrm{C}$

(d)

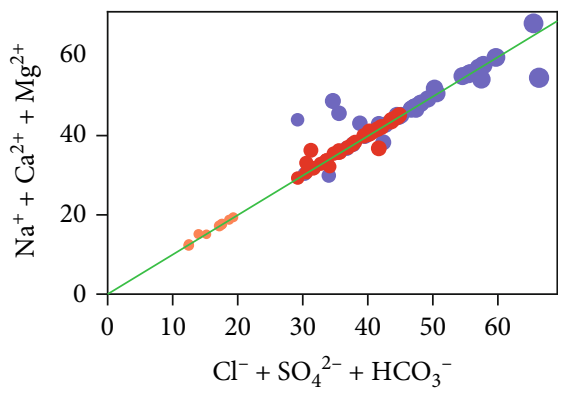

- $\mathrm{Q}$

- $\mathrm{P}$

FIgURE 4: Bubble chart of ion combination of different aquifers.

The expression $\gamma\left(\mathrm{Na}^{+}-\mathrm{Cl}^{-}\right) / \gamma\left(\mathrm{Ca}^{2+}+\mathrm{Mg}^{2+}-\mathrm{SO}_{4}{ }^{2-}-\right.$ $\mathrm{HCO}_{3}{ }^{-}$) is used commonly to reveal the cation exchange rate [33]. Figure 4(e) shows that the Cenozoic and Permian aquifer samples are infinitely close to $y=-x$, and the TDS values are larger, confirming there is cation exchange. Part of the Permian aquifer is above $y=-x$, indicating there may be strong cation exchange. In Figure 4(f), each water sample is close to the $y=x$ line, which shows the mass concentration balance of the anions and cations.

The analytical results of each ion combination ratio show that $\mathrm{Na}^{+}$is mainly derived from salt rock dissolution and cation exchange. $\mathrm{Ca}^{2+}$ and $\mathrm{Mg}^{2+}$ are derived from sul- fate or carbonate dissolution and cation exchange, as shown in Eq. (1). $\mathrm{HCO}_{3}{ }^{-}$and $\mathrm{SO}_{4}{ }^{2-}$ are derived from sulfate and carbonate dissolution. Because the Permian aquifer in the study area is $-350-800 \mathrm{~m}$ below ground surface, it is an overall reducing environment. This means that desulfurization is one of the important sources of $\mathrm{HCO}_{3}{ }^{-}$ in the Permian aquifer, as shown in Eq. (2). Further, there are low sulfate levels and high pyrite levels in the Permian and Carboniferous aquifers. This indicates that the $\mathrm{SO}_{4}{ }^{2-}$ may be derived from pyrite oxidation, as the deep aquifer is in an overall reducing environment. However, some areas are affected by coal mining activities. This leads to the area becoming a semiopen oxidizing environment, 


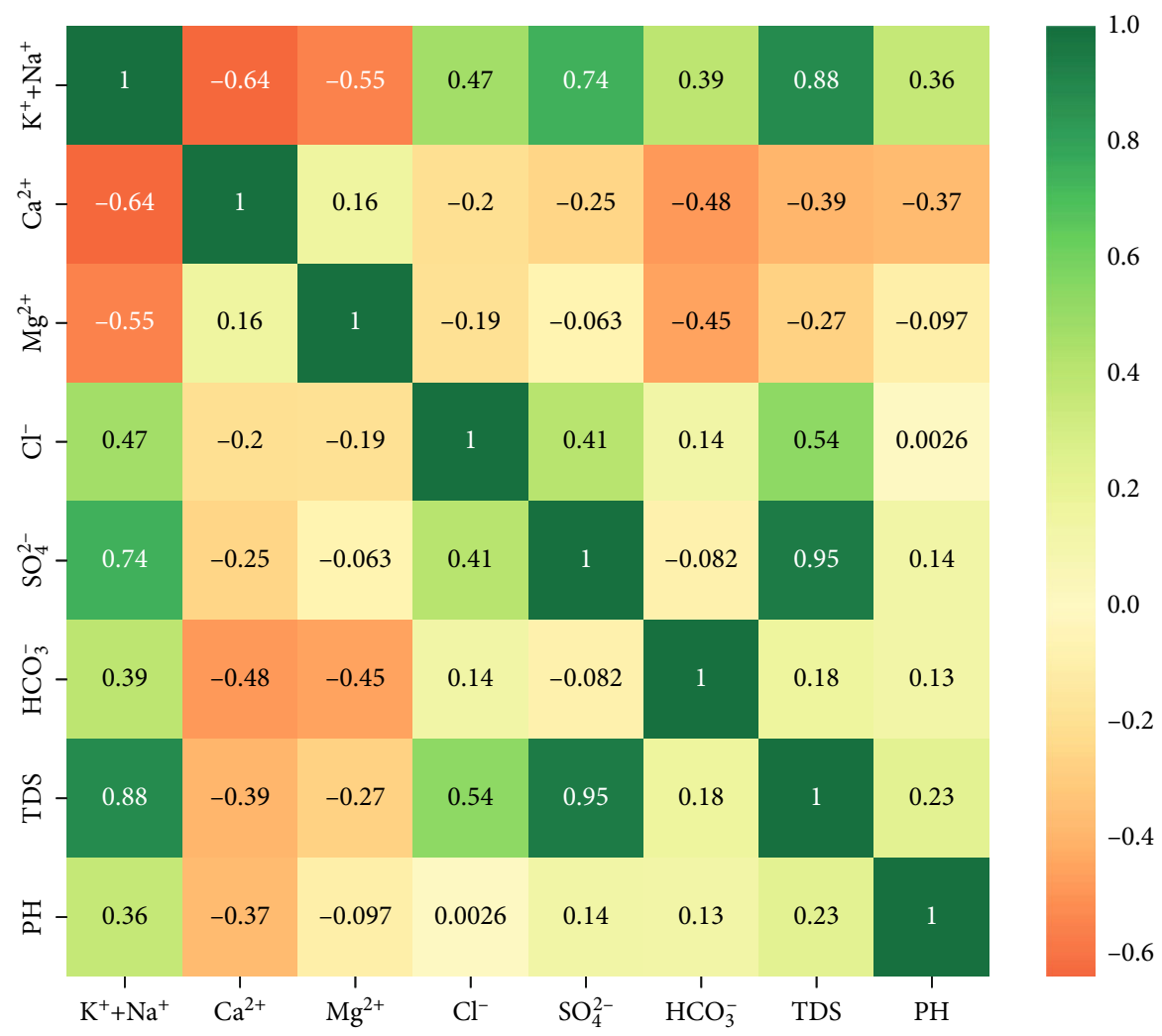

FIGURE 5: Heat map of the correlation coefficient for each parameter.

allowing $\mathrm{CO}_{2}$ and $\mathrm{O}_{2}$ to enter the aquifer and react with pyrite. as shown in Eq.(3).

$$
\begin{gathered}
\mathrm{Na}^{+}(\text {Rock })+\mathrm{Ca}^{2+} / \mathrm{Mg}^{2+}(\text { Water }) \longrightarrow \mathrm{Na}^{+}(\text {Water }) \\
+\mathrm{Ca}^{2+} / \mathrm{Mg}^{2+}(\text { Rock }), \\
\mathrm{SO}_{4}^{2-}+2 \mathrm{C}+2 \mathrm{H}_{2} \mathrm{O} \longrightarrow \mathrm{H}_{2} \mathrm{~S} \uparrow+2 \mathrm{HCO}_{3}^{-}, \\
\mathrm{FeS}_{2}+15 / 4 \mathrm{O}_{2}+7 / 2 \mathrm{H}_{2} \mathrm{O} \longrightarrow \mathrm{Fe}(\mathrm{OH})_{3} \downarrow+2 \mathrm{SO}_{4}^{2-}+4 \mathrm{H}^{+} .
\end{gathered}
$$

3.4. Factor Analysis. Both the R-type factor analysis and principal component analysis provide approximations of the covariance matrix and dimension reduction interpretation of the data set, specifically for the positive index and standardization index automatically executed by the SPSS software [34]. The correlation between variables is determined using a correlation coefficient matrix, and the eigenvalues and eigenvectors of phase relation number matrix are generated. Principal components and factors are linearly independent, and the cumulative contribution rate, index standardization, and index standardization are used. The number of principal components and factors is determined without a loss of variables. The naming basis is the correlation coefficient of principal components, factors, and variables. The difference is that principal component analysis and factor analysis are separate from the initial factor load matrix. The principal component analysis generates the principal component coefficient matrix, principal component, and its value through the unit of the initial factor load array vector or by dividing the corresponding eigenvalue root. The factor analysis generates the factor load matrix by rotating the initial factor load matrix and then obtaining the factor score and its value through regression. The $R$-type factor analysis has the advantage of clearly naming the main factors and enables a clear comprehensive evaluation of the causes [35-37]. The factor analysis method generally includes the following steps [38].

(1) Firstly normalize the indicators, and then standardize the data to eliminate errors caused by large differences in values between variables

(2) Use the SPSS software to obtain total variance explained and rotated component matrix. Total variance explained meets the contribution rate requirement, and the variables in the rotated component matrix are not lost, thereby comprehensively determining $m$ principal factors

(3) Calculate the factor load matrix $B_{m}$ and classify the corresponding variable with the largest absolute value of the $i$ th column of Bm into $\mathrm{Zi}$ category, and then name $\mathrm{Zi}$ for hydrogeochemical effects, which has high clarity

(4) According to the factor score coefficient matrix obtained by the SPSS software, find the expression of the main factor score function: $S_{Z i}=\omega_{i} X$

The correlation coefficient thermograph (Figure 5) directly describes the degree of correlation degree among 
TABLE 2: Explanation of total variance.

\begin{tabular}{lccc}
\hline \multirow{2}{*}{ Component } & \multicolumn{3}{c}{ Extraction sums of squared loadings } \\
& Total & Variance percentage & Cumulative percentage \\
\hline 1 & 2.103 & 35.056 & 35.056 \\
2 & 2.041 & 34.021 & 69.078 \\
\hline
\end{tabular}

TABLE 3: Rotated component score matrix.

\begin{tabular}{lcc}
\hline Parameters & \multicolumn{3}{c}{ Component } \\
\hline $\mathrm{SO}_{4}{ }^{2-}$ & $\mathbf{0 . 9 2 6}$ & 2 \\
$\mathrm{Na}^{+}$ & $\mathbf{0 . 7 9 5}$ & -0.068 \\
$\mathrm{Cl}^{-}$ & $\mathbf{0 . 6 7 7}$ & 0.561 \\
$\mathrm{HCO}_{3}{ }^{-}$ & -0.068 & 0.127 \\
$\mathrm{Mg}^{2+}$ & -0.116 & $\mathbf{0 . 8 9 3}$ \\
$\mathrm{Ca}^{2+}$ & -0.371 & $\mathbf{- 0 . 7 1 9}$ \\
\hline
\end{tabular}

the variables. The $\mathrm{K}^{+}+\mathrm{Na}^{+}$value is positively correlated with $\mathrm{Cl}^{-}, \mathrm{SO}_{4}{ }^{2-}$, and $\mathrm{HCO}_{3}{ }^{-}$. This is due to the existence of rock salt dissolution. The $\mathrm{K}^{+}+\mathrm{Na}^{+}$is negatively correlated with $\mathrm{Ca}^{2+}$ and $\mathrm{Mg}^{2+}$; and TDS is strongly positively correlated with $\mathrm{K}^{+}+\mathrm{Na}^{+}$and is negatively related to $\mathrm{Ca}^{2+}$ and $\mathrm{Mg}^{2+}$. This is caused by cation exchange. There is a weak negative correlation between $\mathrm{SO}_{4}{ }^{2-}$ and $\mathrm{HCO}_{3}{ }^{-}$, indicating that desulfurization has occurred in the aquifers.

The factor analysis method uses the principal component extraction method to generate the total variance explanation shown in Table 2. The cumulative variance contribution rate is $69.078 \%$, and there is no variable loss. Then, two factors $(\mathrm{Z1}, \mathrm{Z2})$ are determined by the rotated component matrix in Table 3. The variance contribution rate of $Z 1$ is $35.056 \%$, which is characterized by a high positive loading of $\mathrm{SO}_{4}{ }^{2-}$ and $\mathrm{Na}^{+}$, and a weak loading of $\mathrm{HCO}_{3}{ }^{-}, \mathrm{Ca}^{2+}$, and $\mathrm{Mg}^{2+}$. This indicates the dissolution of sulfate minerals, pyrite oxidation, and cation exchange. The variance contribution rate of $\mathrm{Z} 2$ is $34.021 \%$, in which $\mathrm{Ca}^{2+}$ and $\mathrm{Mg}^{2+}$ are strongly loaded. $\mathrm{HCO}_{3}{ }^{-}$is strongly positively loaded, and $\mathrm{SO}_{4}{ }^{2-}$ is weakly loaded, indicating the dissolution and desulfurization of calcite and dolomite, respectively. Therefore, $\mathrm{Z} 1$ represents the dissolution of sulfate minerals, pyrite oxidation, and cation exchange, and $\mathrm{Z} 2$ represents the dissolution and desulfurization of calcite and dolomite. These are displayed using Figure 6.

Table 4 shows the factor score coefficients for the six ions of $\mathrm{K}^{+}+\mathrm{Na}^{+}, \mathrm{Ca}^{2+}, \mathrm{Mg}^{2+}, \mathrm{Cl}^{-}, \mathrm{SO}_{4}{ }^{2-}$, and $\mathrm{HCO}_{3}{ }^{-}$in groundwater samples from the Hengyuan coal mine. These were used as the variables for analysis, yielding the following factor score functions:

$$
\begin{gathered}
S_{Z 1}=0.323 x_{1}-0.081 x_{2}+0.075 x_{3}+0.342 x_{4} \\
+0.514 x_{5}-0.208 x_{6}, \\
S_{Z 2}=0.160 x_{1}-0.278 x_{2}-0.379 x_{3}-0.059 x_{4} \\
-0.215 x_{5}+0.511 x_{6} .
\end{gathered}
$$

Substituting the collected data from the 74 water samples into $S_{Z i}$ (Eq. (4) and Eq. (5)) yields the dispersion point diagram illustrating the groundwater factors $\mathrm{Z} 1-\mathrm{Z} 2$ for the Hengyuan mine (Figure 7). The Cenozoic aquifers are mainly distributed in the second quadrant, indicating that calcite and dolomite experience significant dissolution with desulfidation. The Permian aquifers are mainly distributed in the first quadrant, with a partial distribution in the second quadrant. It indicates that the Permian aquifers experience the desulfidation and dissolution of calcite and dolomite and is accompanied by the dissolution of sulfate minerals, pyrite oxidation, and cation exchange. The Carboniferous aquifer samples are mainly located in the third and fourth quadrants, indicating they are mainly affected by sulfate mineral dissolution, pyrite oxidation, and cation exchange. The two Permian aquifer samples in the figure are in the range of Carboniferous aquifers, and a Carboniferous aquifer sample in the range of Permian aquifers. It indicates there may be a hydraulic connection between Permian and Carboniferous aquifers.

3.5. Hydrogeochemical Spatial Evolution Characteristics. The $\mathrm{K}^{+}+\mathrm{Na}^{+}, \mathrm{Ca}^{2+}, \mathrm{Mg}^{2+}, \mathrm{Cl}^{-}, \mathrm{SO}_{4}{ }^{2-}$, and $\mathrm{HCO}_{3}{ }^{-}$values of 74 groundwater samples from the Hengyuan Coal Mine were substituted into the factor score function expression (Eq. (4), Eq. (5)). A Surfer Kriging interpolation was used to draw the load score contour map (Figures 8-10) of the principal factors $\mathrm{Z} 1$ and $\mathrm{Z} 2$. This was used to describe the water chemistry control factors of the multiaquifer system, as follows.

3.6. The Cenozoic Aquifer. Figure 8 shows that the $\mathrm{S}_{\mathrm{Z} 1}$ values are negative in the study area, with a uniform distribution. The $S_{Z 1}$ values range from -2.04 to -1.56 . In contrast, the $S_{Z 2}$ values are positive, with a relatively uniform distribution, and the $S_{Z 2}$ values vary between 0.25 and 1. The $S_{Z 1}$ values gradually increase from west to east, and the $S_{Z 2}$ values gradually decrease. Due to the control of mining activities in the east, the Cenozoic aquifer is discharged, and the groundwater flow accelerates from west to east. This increases the dissolution and contact time of minerals and groundwater. At the same time, the aquifers are in a semioxidized environment during mining activities. In addition, the west area is controlled by structures such as the Wenzhuang syncline and the Mengkou fault, resulting in a relatively closed groundwater environment. From west to east, the sulfate dissolution and cation exchange are enhanced, while the desulfurization effect is weakened.

3.7. The Permian Aquifer. Figure 9 shows that $S_{Z 1}$ values are positive in most of the study area, with an uneven distribution. In the north, the $S_{Z 1}$ values vary from 0.2 to 2.0; in the south, they vary from 0.2 to 1.6 ; and in the east, they vary from -0.8 to 0.2 . $S_{Z 2}$ values are positive and unevenly distributed in the study area, increasing gradually from the north and south sides to the middle. A high $S_{Z 1}$ value and a low $S_{Z 2}$ value appear near the Wenzhuang syncline. Under the action of syncline, this area is a closed 


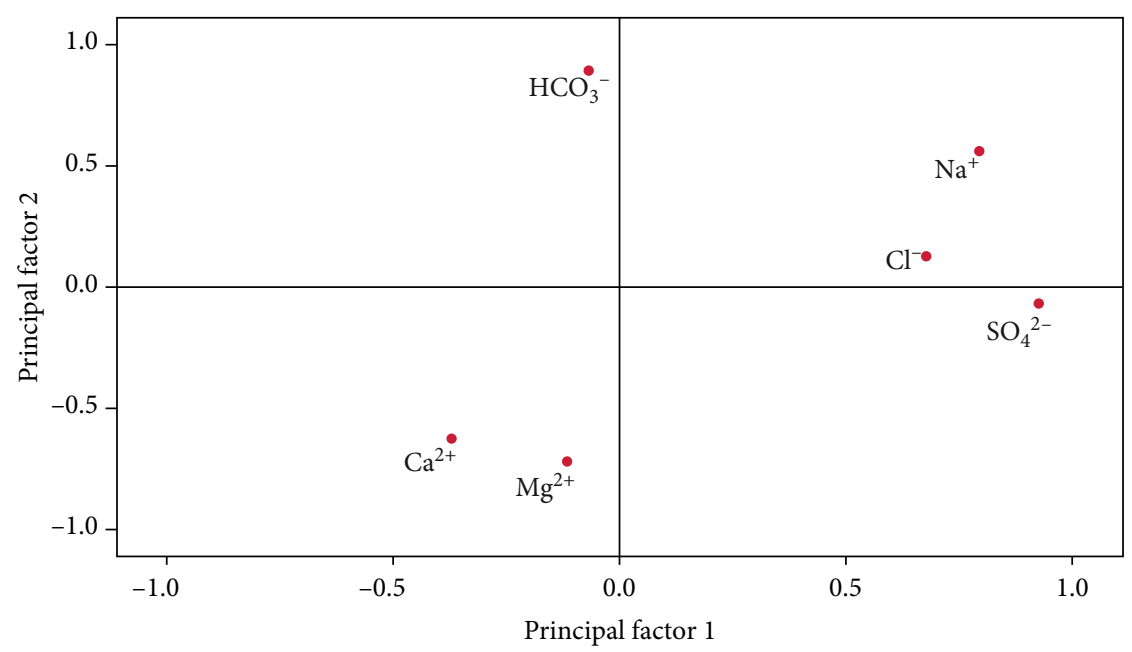

FIGURE 6: Load distribution of each parameter on the principal factor Z1-Z2.

Table 4: Principal factor score coefficients.

\begin{tabular}{lcc}
\hline Parameters & 1 & Principal factor \\
\hline $\mathrm{Na}^{+}$ & 0.323 & 2 \\
$\mathrm{Ca}^{2+}$ & -0.081 & 0.16 \\
$\mathrm{Mg}^{2+}$ & 0.075 & -0.278 \\
$\mathrm{Cl}^{-}$ & 0.342 & -0.379 \\
$\mathrm{SO}_{4}{ }^{2-}$ & 0.514 & -0.059 \\
$\mathrm{HCO}_{3}{ }^{-}$ & -0.208 & -0.215 \\
\hline
\end{tabular}

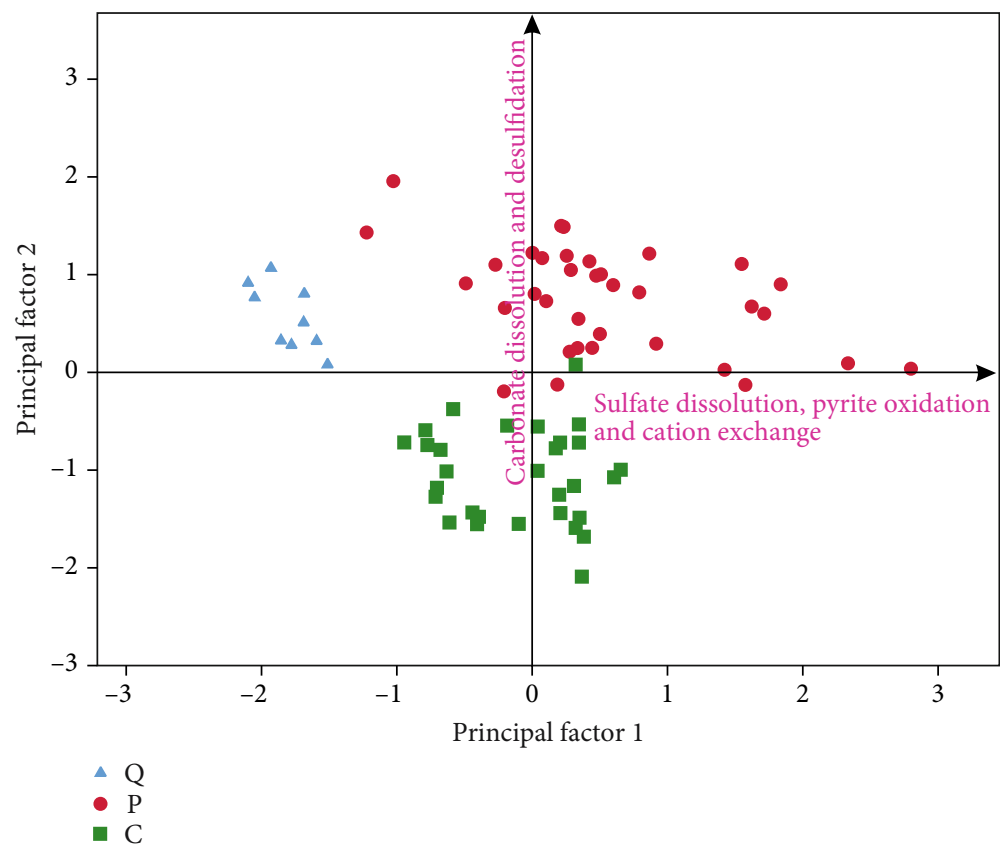

FIGURE 7: Scatter diagram with load scores from aquifer samples. 


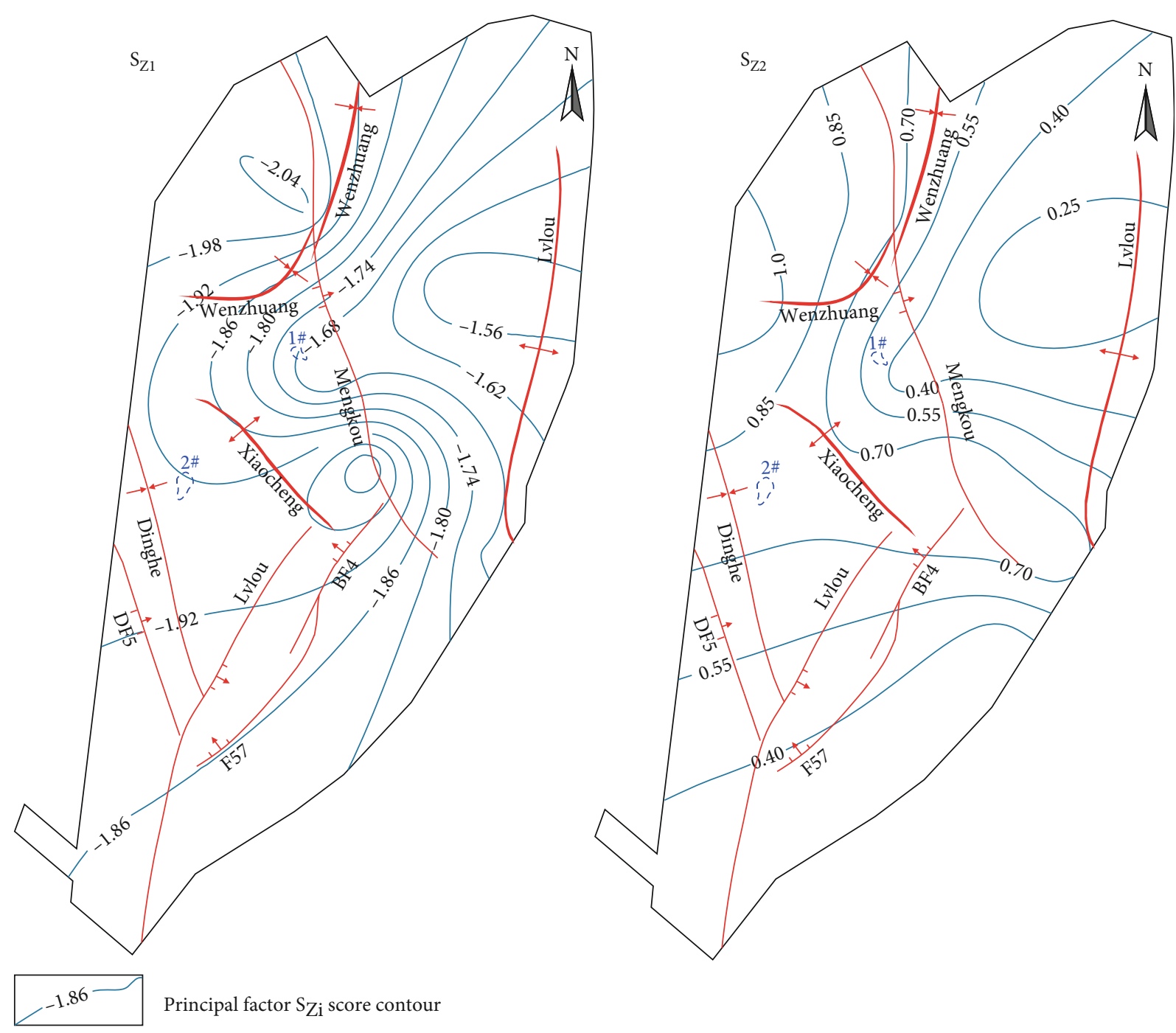

FIGURE 8: Contours of principal loading scores $S_{Z 1}, S_{Z 2}$ for Cenozoic aquifer.

recharge area environment with a strong water yield. There is a long interaction time between groundwater and minerals, enhancing cation exchange and sulfate dissolution. In the area surrounded by the Lvlou fault, the BF4 fault, and the Xiaocheng anticline, the $S_{Z 1}$ value is high and the $S_{Z 2}$ value is low. The aquifers are well sealed, benefitting cation exchange and desulfurization. The $S_{Z 1}$ and $S_{Z 2}$ values are higher from the middle to east. Due to the long-term mining activities, the Permian aquifer has become a semioxidized environment in some areas. This benefits the carbonate and sulfate dissolution and the pyrite oxidation.

3.8. The Carboniferous Aquifer. Figure 10 shows that the $S_{Z 1}$ values in the study area are unevenly distributed; the values gradually decrease to the north between the Xiaocheng anticline and the Lulou anticline and gradually increase to the south of the Xiaocheng anticline. The $S_{Z 2}$ values are all negative. The values are low near the Mengkou fault; the highest value appears to the west of the Mengkou fault. The $S_{Z 2}$ values in the south are lower than other areas overall and are higher at the Lvlou anticline in the east. The mining activities are mainly located in the north wing of the Xiaocheng anticline and the west wing of the Lvlou anticline. The groundwater circulation conditions at the axis of the anticline are good, enhancing the pyrite oxidation, the carbonate dissolution, sulfate dissolution, and cation exchange in the mining area. The groundwater flow near the Wenzhuang syncline is affected by the Mengkou fault, which leads to pyrite oxidation, carbonate and sulfate dissolution, and cation exchange. In contrast, the aquifers at the syncline are deeply buried, leading to increased desulphurization.

\section{Conclusions}

This study investigated the hydrogeochemical evolution characteristics of the complex underground multiaquifer system in Hengyuan Coal Mine in China. Traditional hydrochemical analysis methods and Q-factor analysis methods were used to analyse the collected water samples, leading to the following conclusions. 


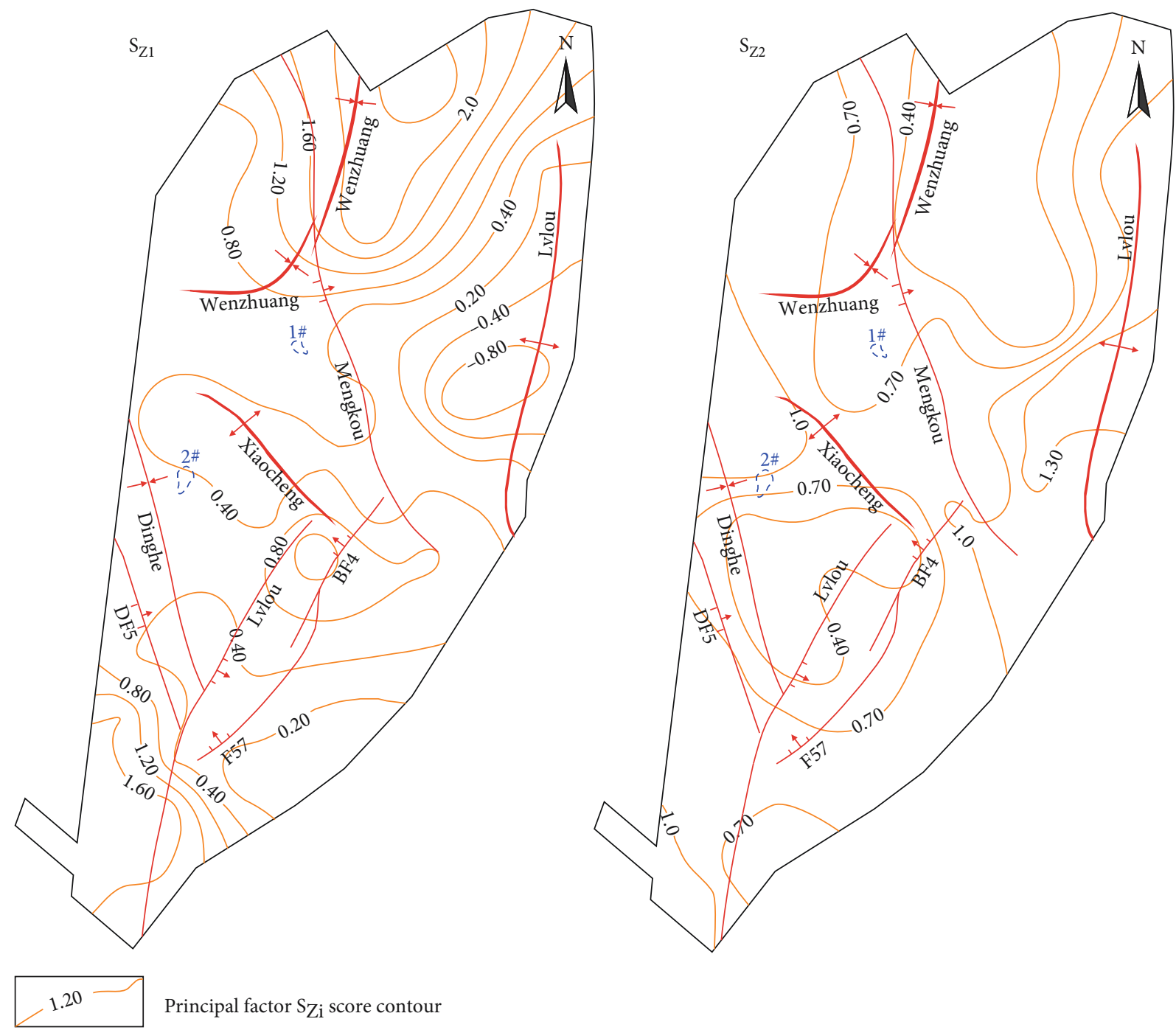

FIgure 9: Contours of principal loading scores $S_{Z 1}, S_{Z 2}$ for Permian aquifer.

(1) The cation levels in the three aquifers were the highest for $\mathrm{K}^{+}+\mathrm{Na}^{+}$, followed in descending order by $\mathrm{Ca}^{2+}$ and $\mathrm{Mg}^{2+}$. In the Permian and Carboniferous aquifers, $\mathrm{SO}_{4}{ }^{2-}$ was present at the highest levels, followed by $\mathrm{HCO}_{3}{ }^{-}$and $\mathrm{Cl}^{-}$. In the Cenozoic aquifers, $\mathrm{HCO}_{3}^{-}$was the highest, followed by $\mathrm{SO}_{4}{ }^{2-}$ and $\mathrm{Cl}^{-}$. The overall TDS values of each aquifer were the highest for the coal, followed by the Taihui and Cenozoic. The TDS values successively decreased in the Permian, Carboniferous, and Cenozoic aquifers. The difference in ion skewness in different aquifers is due to the comprehensive reflection of different hydrogeochemical processes

(2) The hydrogeological conditions and mining activities impact the hydrogeochemical processes of the Hengyuan coal mine. These processes mainly include carbonate and sulfate dissolution, cation exchange, desulfurization, and pyrite oxidation. Carbonate dissolution and desulfurization are significant in the Cenozoic aquifer, and the cation exchange and pyrite oxidation in the Permian aquifers are the most significant. There is significant sulfate dissolution, cation exchange, and pyrite oxidation in the Carboniferous aquifers

(3) The hydrogeochemical evolution process in underground aquifers is mainly controlled by mining activities, faults, and folds, and the hydrogeochemical evolution process of aquifers in the study area shows obvious zonation

Studying the chemical changes of groundwater can provide a geological basis for the accurate identification of potential water inrush sources and protection of water resources and has certain guiding significance for coal mine safety production. The chemical evolution of groundwater is a dynamic process, and water chemistry data should be collected regularly to find out the changes of groundwater in 


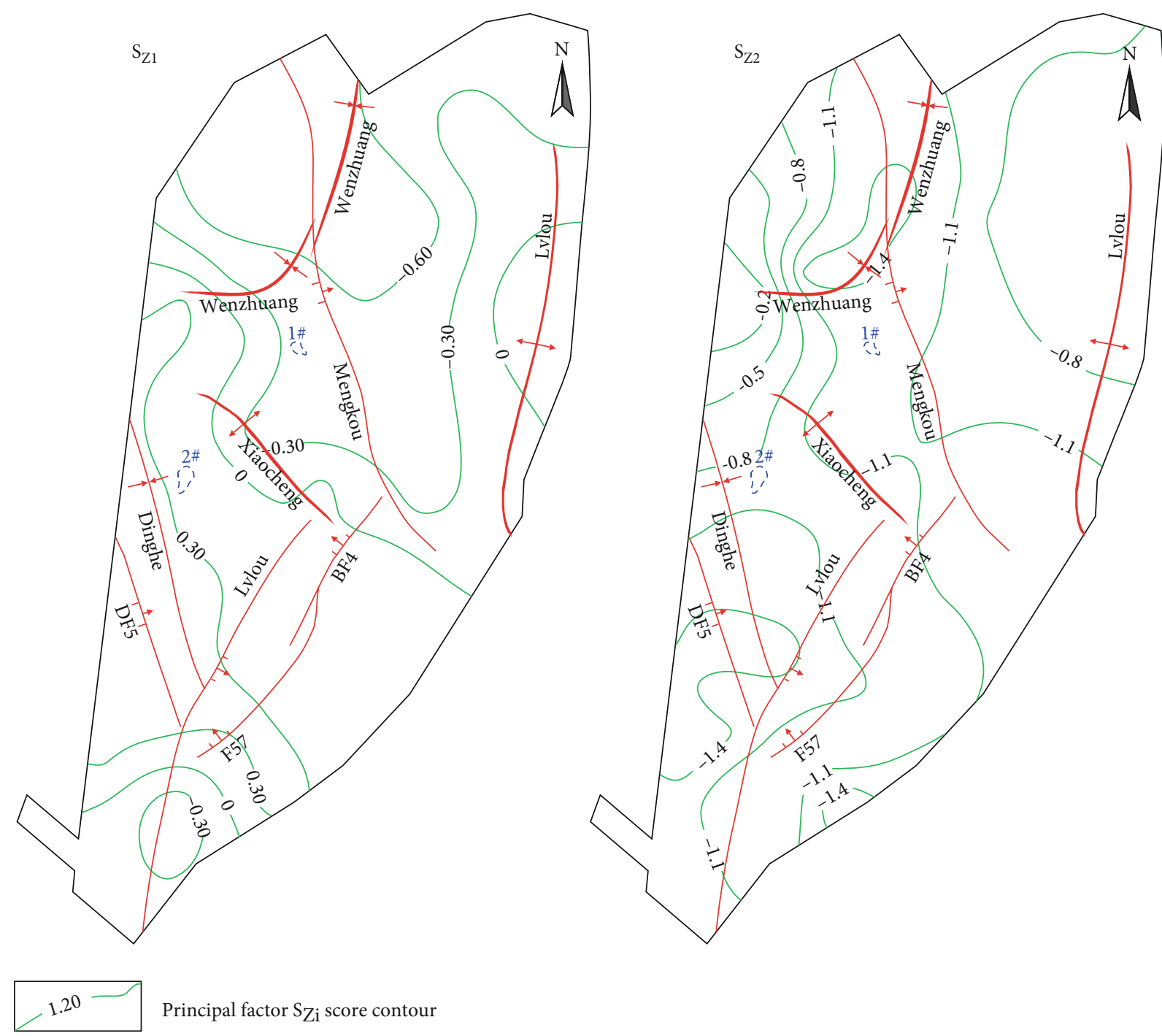

Figure 10: Contours of principal loading scores $S_{Z 1}, S_{Z 2}$ for Carboniferous aquifer.

coal mine areas. In the future, we can study the evolution process of ground hydrology and geochemistry from the perspective of time and space.

\section{Data Availability}

The data used to support the findings of this study are available from the corresponding author upon request.

\section{Conflicts of Interest}

The authors declare that they have no conflicts of interest.

\section{Acknowledgments}

We gratefully acknowledge the support provided by the National Key Research and Development Program of China (NO.2017YFC0804101), the Natural Science Foundation of Anhui Province (NO.2008085QD191 and NO.1908085ME144), and the Independent Research fund of The State Key Laboratory of Mining Response and Disaster Prevention and Control in Deep Coal Mines (Anhui University of Science and Technology) (NO.SKLMRDPC19ZZ06). The authors would also like to thank Dr. Huichan Chai, Dr. Shuhao Shen, and Dr. Yaoshan $\mathrm{Bi}$ for his valuable comments and suggestions for improvement of the manuscript.

\section{References}

[1] Z. Li, B. Zhou, D. Teng, W. Yang, and D. Qiu, "Comprehensive evaluation method of groundwater environment in a mining area based on fuzzy set theory," Geosystem Engineering, vol. 21, no. 2, pp. 103-112, 2017.

[2] S. M. Gorelick and C. M. Zheng, "Global change and the groundwater management challenge," Water Resources Research, vol. 51, no. 5, pp. 3031-3051, 2015.

[3] D. A. Tran, M. Tsujimura, L. P. Vo, V. T. Nguyen, D. Kambuku, and T. D. Dang, "Hydrogeochemical characteristics of a multi-layered coastal aquifer system in the Mekong 
Delta, Vietnam," Environmental Geochemistry and Health, vol. 42, no. 2, pp. 661-680, 2020.

[4] H. Yin, H. Zhao, D. Xie, S. Sang, Y. Shi, and M. Tian, "Mechanism of mine water inrush from overlying porous aquifer in Quaternary: a case study in Xinhe Coal Mine of Shandong Province, China," Arabian Journal of Geosciences, vol. 12, no. 5, 2019.

[5] P. Li, J. Wu, R. Tian et al., "Geochemistry, hydraulic connectivity and quality appraisal of multilayered groundwater in the Hongdunzi Coal Mine Northwest China," Mine Water and the Environment, vol. 37, no. 2, pp. 222-237, 2018.

[6] Y. Xiao, J. Shao, Y. Cui, G. Zhang, and Q. Zhang, "Groundwater circulation and hydrogeochemical evolution in Nomhon of Qaidam Basin, northwest China," Journal of Earth System Science, vol. 126, no. 2, 2017.

[7] V. Cloutier, R. Lefebvre, R. Therrien, and M. M. Savard, "Multivariate statistical analysis of geochemical data as indicative of the hydrogeochemical evolution of groundwater in a sedimentary rock aquifer system," Journal of Hydrology, vol. 353, no. 34, pp. 294-313, 2008.

[8] C. Güler, M. A. Kurt, M. Alpaslan, and C. Akbulut, "Assessment of the impact of anthropogenic activities on the groundwater hydrology and chemistry in Tarsus coastal plain (Mersin, SE Turkey) using fuzzy clustering, multivariate statistics and GIS techniques," Journal of Hydrology, vol. 414-415, pp. 435-451, 2012.

[9] P. Huang and J. Chen, "Recharge sources and hydrogeochemical evolution of groundwater in the coal-mining district of Jiaozuo, China," Hydrogeology Journal, vol. 20, no. 4, pp. 739-754, 2012.

[10] W. G. Cao, H. F. Yang, C. L. Liu, Y. J. Li, and H. Bai, "Hydrogeochemical characteristics and evolution of the aquifer systems of Gonghe Basin, Northern China," Geoscience Frontiers, vol. 9, no. 3, pp. 907-916, 2018.

[11] L. Chen, W. Xie, X. Feng, N. Zhang, and X. Yin, "Formation of hydrochemical composition and spatio-temporal evolution mechanism under mining-induced disturbance in the Linhuan coal-mining district," Arabian Journal of Geosciences, vol. 10, no. 3, 2017.

[12] H. Zhang, G. Xu, X. Chen et al., "Groundwater hydrogeochemical processes and the connectivity of multilayer aquifers in a coal mine with karst collapse columns," Mine Water and the Environment, vol. 39, no. 2, pp. 356-368, 2020.

[13] M. Gomo and D. Vermeulen, "Hydrogeochemical characteristics of a flooded underground coal mine groundwater system," Journal of African Earth Sciences, vol. 92, pp. 68-75, 2014.

[14] E. D. Sunkari, M. Abu, M. S. Zango, and A. M. Lomoro Wani, "Hydrogeochemical characterization and assessment of groundwater quality in the Kwahu-Bombouaka Group of the Voltaian Supergroup, Ghana," Journal of African Earth Sciences, vol. 169, p. 103899, 2020.

[15] E. D. Sunkari and M. Abu, "Hydrochemistry with special reference to fluoride contamination in groundwater of the Bongo district Upper East Region, Ghana," Sustainable Water Resources Management, vol. 5, no. 4, pp. 1803-1814, 2019.

[16] E. D. Sunkari, M. S. Zango, and H. M. Korboe, "Comparative analysis of fluoride concentrations in groundwaters in northern and southern Ghana: implications for the contaminant sources," Earth Systems and Environment, vol. 2, no. 1, pp. 103-117, 2018.
[17] P. Huang, Z. Yang, X. Wang, and F. Ding, "Research on PiperPCA-Bayes-LOOCV discrimination model of water inrush source in mines," Arabian Journal of Geosciences, vol. 12, no. 11, 2019.

[18] X. Guo, R. Zuo, J. Wang et al., "Hydrogeochemical evolution of interaction between surface water and groundwater affected by exploitation," Groundwater, vol. 57, no. 3, pp. 430-442, 2018.

[19] H. Zhang, H. Xing, D. Yao, L. Liu, D. Xue, and F. Guo, “The multiple logistic regression recognition model for mine water inrush source based on cluster analysis," Environmental Earth Sciences, vol. 78, no. 20, 2019.

[20] H. Zhang, G. Xu, X. Chen, J. Wei, S. Yu, and T. Yang, "Hydrogeochemical characteristics and groundwater inrush source identification for a multi-aquifer system in a coal mine," Acta Geologica Sinica-English Edition, vol. 93, no. 6, pp. 19221932, 2019.

[21] X. Zhang, X. Li, and X. Gao, "Hydrochemistry and coal mining activity induced karst water quality degradation in the Niangziguan karst water system China," Environmental Science and Pollution Research, vol. 23, no. 7, pp. 6286-6299, 2016.

[22] H. Zhang, G. Xu, X. Chen, and A. Mabaire, "Hydrogeochemical evolution of multilayer aquifers in a massive coalfield," Environmental Earth Sciences, vol. 78, no. 24, 2019.

[23] K. A. R. Kpegli, A. Alassane, R. Trabelsi et al., "Geochemical processes in Kandi Basin, Benin, West Africa: a combined hydrochemistry and stable isotopes approach," Quaternary International, vol. 369, pp. 99-109, 2015.

[24] P. Li, J. Wu, H. Qian et al., "Hydrogeochemical characterization of groundwater in and around a wastewater irrigated forest in the southeastern edge of the Tengger Desert, Northwest China," Exposure and Health, vol. 8, no. 3, pp. 331-348, 2016.

[25] M. Meybeck, "Global chemical weathering of surficial rocks estimated from river dissolved loads," American Journal of Science, vol. 287, no. 5, pp. 401-428, 1987.

[26] I. Farid, R. Trabelsi, K. Zouari, and R. Beji, "Geochemical and isotopic study of surface and groundwaters in Ain Bou Mourra basin, central Tunisia," Quaternary International, vol. 303, pp. 210-227, 2013.

[27] Z. Liang, J. Chen, T. Jiang et al., "Identification of the dominant hydrogeochemical processes and characterization of potential contaminants in groundwater in Qingyuan, China, by multivariate statistical analysis," RSC Advances, vol. 8, no. 58, pp. 33243-33255, 2018.

[28] P. Huang and S. Han, "Study of multi-aquifer groundwater interaction in a coal mining area in China using stable isotopes and major-ion chemical data," Environmental Earth Sciences, vol. 76, no. 1, pp. 2-10, 2017.

[29] P. Li, X. He, Y. Li, and G. Xiang, "Occurrence and health implication of fluoride in groundwater of loess aquifer in the Chinese loess plateau: a case study of Tongchuan, Northwest China," Exposure and Health, vol. 11, no. 2, pp. 95-107, 2019.

[30] J. Qian, Y. Tong, L. Ma, W. Zhao, R. Zhang, and X. He, "Hydro-chemical characteristics and groundwater source identification of a multiple aquifer system in a coal mine," Mine Water and the Environment, vol. 37, no. 3, pp. 528$540,2018$.

[31] L. W. Chen, D. Q. Xu, X. X. Yin, W. P. Xie, and W. Zeng, "Analysis on hydrochemistry and its control factors in the concealed coal mining area in North China: a case study of dominant inrush aquifers in Suxian mining area," Journal of China Coal Society, vol. 4, no. 42, pp. 996-1004, 2017. 
[32] K. Schacht and B. Marschner, "Treated wastewater irrigation effects on soil hydraulic conductivity and aggregate stability of loamy soils in Israel," Journal of Hydrology and Hydromechanics, vol. 63, no. 1, pp. 47-54, 2015.

[33] P. Li, J. Wu, and H. Qian, "Hydrochemical appraisal of groundwater quality for drinking and irrigation purposes and the major influencing factors: a case study in and around Hua County, China," Arabian Journal of Geosciences, vol. 9, no. 1, p. 15, 2016.

[34] S. Jung and S. Seo, "A comparative study on factor recovery of principal component analysis and common factor analysis," Korean Journal of Applied Statistics, vol. 26, no. 6, pp. 933942, 2013.

[35] Z. Hoseinzade and A. R. Mokhtari, "A comparison study on detection of key geochemical variables and factors through three different types of factor analysis," Journal of African Earth Sciences, vol. 134, pp. 557-563, 2017.

[36] J. H. Lee, J. H. Yoon, J. Y. Cheong, H. Jung, and S. G. Kim, "Hydrogeochemical evaluation of crystalline bedrock grondwater in a coastal area using principal component analysis," Journal of Soil and Groundwater Environment, vol. 22, no. 3, pp. 10-17, 2017.

[37] A. Dinno, "Implementing Horn's parallel analysis for principal component analysis and factor analysis," The Stata Journal: Promoting communications on statistics and Stata, vol. 9, no. 2, pp. 291-298, 2018.

[38] R. Aparecida Mendonça Marques, R. Bruno Dutra Pereira, R. Santana Peruchi, L. Cardoso Brandão, J. Roberto Ferreira, and J. Paulo Davim, "Multivariate GR\&R through factor analysis," Measurement, vol. 151, article 107107, 2020. 